\title{
Between Ottomanization and Local Networks: Appointment Registers as Archival Sources for Waqf Studies. The Case of Jerusalem's Maghariba Neighborhood
}

\author{
Şerife Eroğlu Memiş
}

This study presents the 'atīk (old) and cedid (new) appointment registers located in Ankara in the Archive of the General Directorate of Foundations in Turkey, and discusses their importance for the social and economic history of Jerusalem after 1840 . They are composed mainly of records of appointments, promotions, and dismissals of waqf employees, and were continually updated. This article focuses on the registers of the Maghariba neighborhood, a unique example of an area founded as a waqf quarter; an unprecedented event in Islamic history. Although a number of studies have explored the establishment of the quarter and its awqāf (Ar. s. waqf; Ott. vakf, pl. evkaf), ${ }^{1}$ the changing nature of these institutions over time merits more attention.

The word waqf and its plural form $a w q \bar{a} f$ are derived from the Arabic root verb waqafa, which means to cause something to stop and stand still. In the Ottoman Empire, the word waqf was also used to describe a sophisticated philanthropic foundation; a revenue-generating property in which a part of the

1 See for example Mujir al-Din al-'Ulaymi al-Hanbali, Al-Uns al-Jalil bi-Tarikh al-Quds wa-lKhalil [The glorious history of Jerusalem and Hebron], 2 vols. (Amman, 1973); Abdul Latif Tibawi, The Islamic Pious Foundations in Jerusalem (London: Islamic Cultural Centre, 1978); Ador Arnon, "The Quarters of Jerusalem in the Ottoman Period," Middle Eastern Studies 28, no. 1 (1992); Tom Abowd, "The Moroccan Quarter: A History of the Present," Jerusalem Quarterly, no. 7 (200o); Kamil Jamil Asali, "Haratu'l-Maghariba fi al-Quds wa Ahammiyyatuha at-Tarihiyya" [Maghariba quarter in Jerusalem and its importance in history], in Al-Buhus ve al-Dirasatve al-Makalat [Matters, studies and the articles], 2 vols. (Amman:Vezaretu's-Sakafe, 2009), 19; Muhammad Hashim Musa Dawud Ghushah, Al-Awqāf al-Islamiyah fi-l-Quds alsharif: dirasa tarikhiyya muwathaqa [Islamic awqāfin Jerusalem: a historical documentation] (Istanbul: IRCICA, 2009); Hasan H. Güneş, "Kudüs'te Bir Mahalle: Sekiz Yüz Ylllık Meğāribe Mahallesi ve Serencamı" [A Waqf neighborhood in Jerusalem: The Magarebeh neighborhood of eight hundred years and its adventure], Vakıflar Dergisi 44 (2015).

(C) ŞERIFE EROĞLU MEMIŞ, 2018 | DOI:10.1163/9789004375741_007

This is an open access chapter distributed under the terms of the prevailing CC-BY-NC-ND License at the time of publication. 
revenue is disbursed for a pious purpose in order to seek God's favor. ${ }^{2}$ More than five decades of empirically-based research in the Ottoman archives have contributed to a clear understanding of the depth of influence awqāf had on the societies in which they operated. Awqā $f$ oversaw a number of public, charitable, and religious activities, and their reach extended to all socioeconomic levels of society. As uniquely autonomous institutions in terms of administration, fiscal management, and the provision of public order and security, awqā $f$ constitute an interesting topic of historical study, particularly from the standpoint of the history of settlement and citadinité.

Awq $\bar{a} f$ were one of the major institutions in Jerusalem from the Muslim conquest of the city until the end of the nineteenth century. During this time, the area of Haram al-Sharif, which included al-Aqsā mosque and the Dome of the Rock, became the nucleus of the Muslim waqf network ${ }^{3}$ in the city. Awqa $f$ carried out various charitable and religious activities in the city such as feeding the poor and students at the Hasseki Sultan Soup Kitchen. The revenue generated by awqāf also went toward the financing of a number of public services including the construction and maintenance of irrigation systems and aqueducts, and some of the municipal services run jointly by the guilds and the awqāf. Revenue from the waqf endowed by Saladin funded the maintenance and operation of the biggest hospital in the city. In addition, the awqāf built and ran schools (madrasa), and provided religious services such as the building of mosques in Jerusalem. In contrast to the Ayyubids and the Mamluks, who gave priority to religious and educational $a w q \bar{a} f$ in the city, the Ottomans invested in the city's infrastructure. ${ }^{4}$ They preferred to spend the appropriations and donations given to the city on projects such as improving security and the water supply, and on building a new open-air market. These initiatives aimed to show that the Ottomans were increasing the prosperity of Jerusalem. ${ }^{5}$

2 Ömer Hilmi Efendi, İthaf-Ül-Ahlaf Fi Ahkam-İl-Evkaf [Laws relating to foundations] (Ankara: Vakıflar Genel Müdürlüğü Yayınları, 1977), 13; For more detailed information, see David Stephan Powers, "Waqf," Encyclopedia of Islam, 2nd ed., vol. 40 (2002).

3 Şerife Eroğlu Memiş, "Osmanlı Taşra Toplumu ve Vakıf Kurumu: Kudüs, 1703-1831” [Ottoman provincial society and the waqf: Jerusalem, 1703-1831] (PhD diss., Hacettepe University, 2016), 12-16.

4 Dror Ze'evi, An Ottoman Century: The District of Jerusalem in the 16oos (Albany: Syracuse University Press, 1996), 31; Yasemin Avcı, Değişim Sürecinde Bir Osmanlı Kenti, Kudüs (18901914) [An Ottoman city in the period of transformation: Jerusalem, 1890-1914] (Ankara: Phoenix, 2004), 36.

5 André Raymond, "The Ottoman Conquest and the Development of the Great Arab Towns," International Journal of Turkish Studies 1 (1979-80). 
The present study focuses on the role of awqā in the Maghariba neighborhood of Jerusalem. While endowment deeds (waqfiyya $t)^{6}$ are the most valuable and rich resources for waqf studies, they do not provide us with adequate information on the actual nature of the social and economic activities of a waqf, or on the changes in these activities over time. The waqfiyyāt must be supported by other primary sources such as the appointment registers (esāa) şąsiyāt).

The first part of this article presents general information about the registers from the records of the awqāf of the Maghariba neighborhood. The second part touches briefly on the founding of the neighborhood and its awqāf, and on the significance of the Maghariba neighborhood for Jerusalem. Part three analyzes the appointment records for waqf endowments in detail in order to shed light on the employment policies of the Ottoman state in a provincial town, in which it maintained control through postings and entitlements to waqf stipends.

\section{The Old and New Registers of the Maghariba Neighborhood: before and after 1882}

The Archive of the General Directorate of Foundations (VGMA), located in Ankara, specializes in waqf registers and documents. It houses 610 old appointment and 136 new registers. ${ }^{7}$ The 'atīk registers were also called treasury registers and covered the appointment records of waqf staff before 1300/1882. These are mainly composed of the Istanbul, Anatolian, Rumelian, and Haramayn (Mecca and Medina) series. Although these registers have been

6 For more on the importance of waqf documents, see Fuad Köprülü, "Vakıf Müessesesinin Hukuki Mahiyeti ve Tarihi Tekamülü” [Legal status and evolution of waqf institution], Vakıflar Dergisi 2 (1942); Ömer Lütfi Barkan, "Edirne ve Civarındaki Bazı İmaret Tesislerinin Yllık Muhasebe Bilançoları" [Annual accountancy balances of some Imārah facilities in and around Edirne], Türk Tarih Belgeleri Dergisi 1, no. 2 (1964): 237-39.

7 The Archive of the General Directorate of Foundations (VGMA) houses the records related to $a w q \bar{a} f$ in the Ottoman Empire. For the history of this institution, the number of records stored there and its present situation, as well as the stages in the official founding of the VGMA, see Kani Özyer, "Vakıflar Genel Müdürlüğü Arşivi” [Archive of the General Directorate of Foundations], in Uluslar arası Türk Arşivleri Sempozyumu [Turkish Archive Symposium], 17-19 November 2005 (Istanbul: вОА Publications, 2006); Mustafa Alkan, "Türk Tarihi Araştırmaları Açısından Vakıf Kayıtlar Arşivi" [Waqf records archive from the perspective of Turkish historical studies], Vakıflar Dergisi 30 (2007). 
mentioned in some studies on the VGMA collections, no study has yet assessed the two collections together.

The registers are bound in leather, cloth, or marbled paper, and are written in the inaccessible siyakat writing style, which may explain why studies have not dealt with them. Siyakat refers to letters and numbers expressed in the "stairs" style of writing, used in Ottoman accounting documents to establish a powerful regime of surveillance, inspection, and communication. ${ }^{8}$ Each register starts with an index page. In the index, the records are organized under the headings of the district names and the records were entered on this basis. Records are usually written vertically. The contents provide detailed information about the administrative structure of the area, the names of the district, names of the awqā $f$ and their founders, types of work, previous and current names of office holders, reasons for new postings, fees, names of administrators who can request different postings, and the dates of documents recorded in a specific order and sequence.

Another important detail that appeared in the records was the reason for the appointment. Possibilities were renewal (mujaddid), vacancy (makhlül), removal or suspension (kasr al-yad, kaff al-yad), quitting, or resignation in favor of another person (färigh). The waqf staff was considered to be part of the ruling class ('asker $\iota^{-9}$ ) in the social structure of the Ottoman state, and was therefore exempted from taxes..$^{10}$ All staff salaries were paid by the waqf

8 For detailed information on the șiyakat writing style, see Mübahat S. Kütükoğlu, Osmanlı Belgelerinin Dili: diplomatik [The language of Ottoman documents: diplomatic] (Istanbul: Kubbealtı Akademisi Kültür ve San’at Vakfı, 1994), 64-67; Hilmi Erdoğan Yayla, "Accounting and the Art of Writing" (paper presented at the 19th Accounting, Business and Financial History Conference, Cardiff Business School, September 2007, and the 31st annual congress of the European Accounting Association, Erasmus University, April 2008).

9 Studies on Ottoman social structure and Ottoman society fall into two main classes. Usually, the ruling elite or ruling class, which was differentiated from ordinary taxpayers ( re $\bar{a} y \bar{a})$, was composed of people who had religious or administrative power as granted by a sultan's charter. This was a service-based nobility, which was composed of the officials who were affiliated with the palace and the military, civil servants and "scholars." Halil İnalcık, "The Nature of Traditional Society: Turkey," in Political Modernization in Japan and Turkey, ed. Robert E. Ward and Dankwart A. Rustow (Princeton: Princeton University Press 1964), 44. See also Abdul-Karim Rafeq, "Political Power and Social Networks: Popular Coexistence and State Oppression in Ottoman Syria," in Islamic Urbanism in Human History: Political Power and Social Networks, ed. Tsugitaka Sato (London: Kegan Paul International 1997), 22.

10 Some of the registers in the series are labeled Aleppo Ruling Class (Halep Askerī), Province of Yemen Ruling Class (Vilayet-i Yemen 'Askerī), with a specific reference to the status of waqf staff among the ruling class. See VGMA $529,5^{26}$. 
administrations as designated and included in the waqfyya.${ }^{11}$ Requests for appointments within the Ottoman bureaucracy were submitted by the chief judge (każasker). ${ }^{12}$

While the records in the 'atik registers are arranged according to their administrative units, the cedid structure is identical to the waqf registers. These registers began to be kept after 1300/1882, with a specific reference to the 'atik. series. These are also hardcover volumes bound in leather, cloth, or marbled paper, written in rik'a, rik'a crumble, dìvanī or $t \bar{a} \bar{l}^{\prime} \bar{k} k$ style. The records are usually written horizontally. Four series of registers make up this collection. ${ }^{13}$ The cedìd registers are also organized differently than the 'atikk registers and are written in a systematic way in a chart called the "Register of Professions" (Defter Esās Cihāt). All new appointments and other additions are written in the events section of the chart. Thus, this chart acts as a summary of the activities of the waqfiyya.

The records of the Maghariba neighborhood are located in number 515 of the 'atīk registers (Kudüs 'atīk) (fig. 4.1) and in number 160 of the cedìd (Kudüs cedīd) registers (fig. 4.2). There is also an index register numbered 163 called the Index of Benghazi and Jerusalem, which includes the index of the 'atīk and cedīd registers. ${ }^{14}$ In the 515 Jerusalem 'atīk register, there are 594 records written according to the district names, 137 of which are written under the heading "Awqā $f$ of the District of Jerusalem."

11 Bahaeddin Yediyıldız, "Müessese-Toplum Münasebetleri Çerçevesinde XvıII. Asır Türk Toplumu ve Vakıf Müessesesi” [On the framework of institution-society relations in 18thcentury Turkish society and waqf institutions], Vakıflar Dergisi 15 (1982).

The appointee received a certificate called an appointment deed (berāt) issued by the chief judge. The District of Jerusalem was under the jurisdiction of the Anatolian chief judge. In the Ottoman state there were two offices of the chief judge: the Anatolian and Rumelian chief justices. One dealt with affairs related to the districts of Rumelia and the Aegean Islands and the other dealt with Anatolia, Egypt, Syria and other districts in the Arabian Peninsula. See Mehmet İpşirli, "Osmanlı Devleti'nde Kazāskerlik (xvir. Yüzylla kadar)" [The office of chief judge in the Ottoman state (up to the 17 th century)], Belleten 61, no. 232 (1997): 640-41.

13 For detailed information on the series, see Alkan, "Türk Tarihi Araştırmaları," 8-9.

14 In the archive, there are many index registers providing details on the registers. See for example the Index of Baghdad, Aleppo, Mosul: vGMA 165; Index of Monastir and Kosovo: VGMA 172; Index of Adrianople: vgma 173; Index of Thessaloniki: vgma 178; Index of Ioannina, Shkodër, Crete, Mediterranean islands, Cyprus: VGMA 181; Index of Ḥaramayn: VGMA 753; Index of Rumelia: VGMA 755. 


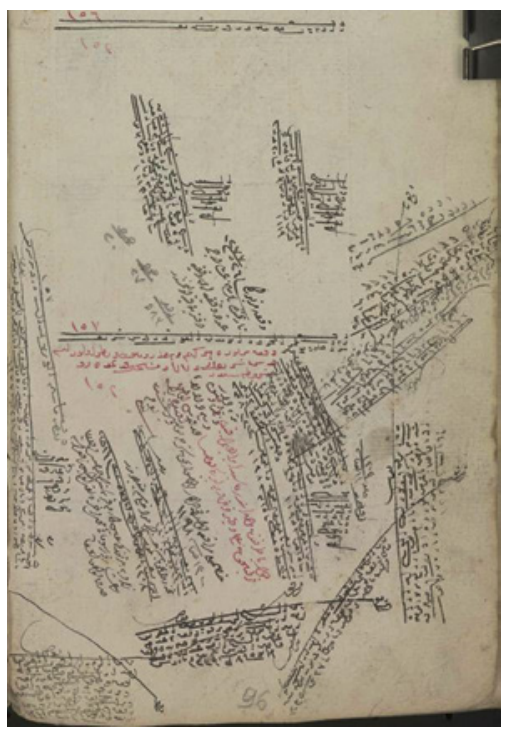

FIGURE 4.1

Atik (Old) record of the "Waqf of the Tombs of Abu Madyan al-Ghawth and Umar al-Mujarrad." VGMA, 515: 97/157.

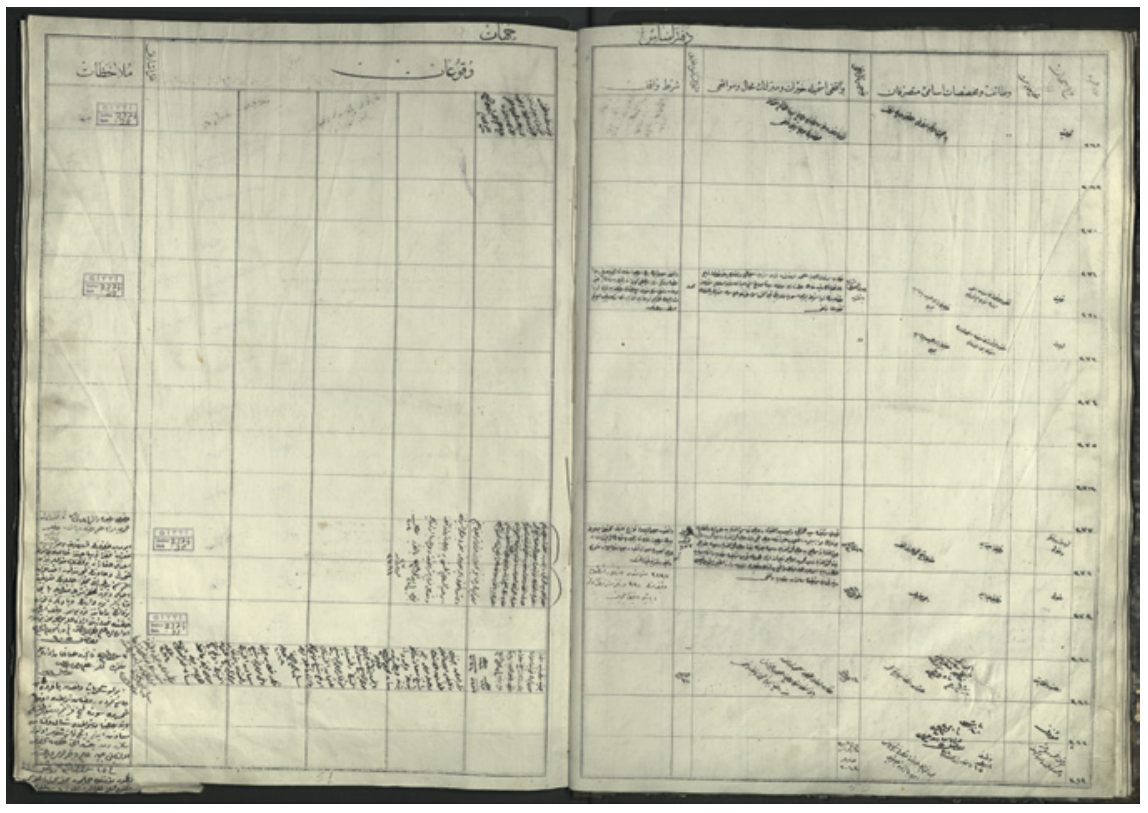

FIGURE 4.2 Cedid (New) record.

VGMA, 160: 50/378-79. 
The records of the awqā $f$ of the Maghariba neighborhood before 1882 are also recorded on different pages. ${ }^{15}$ Each record starts with a heading that indicates the name of the waqf. For example, "Waqf of Zawiya Maghariba in Jerusalem" or "Waqf of the Tombs of Sayyid "Umar al-Mujarrad and Abu Madyan alGhawth in Jerusalem." Each member of the staff is recorded in a triangleshaped space filled with five pieces of information: name of the staff member, ${ }^{16}$ title of the office, share, salary and the periodicity of payment (daily, monthly or yearly). For example, Sheikh Osman, son of Sheikh Muhammad al-Maghribi, was appointed as mutawalli and sheikh with a half share and $1.5 \mathrm{kirsh}$ salary per day. ${ }^{17}$

In 160 Jerusalem Cedīd Esās, there are 142 pages; however, only 46 pages include records. Out of the total of 760 records, between 1 and 137 are

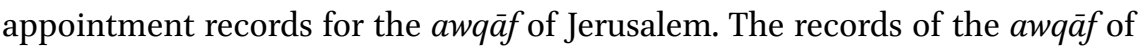
the Maghariba neighborhood after 1882 are written on different pages. ${ }^{18}$ The 'atïk and cedìd appointment registers are therefore highly consistent, and should be examined with an integrated approach. While the Cedid registers start with the last record in the 'atïk registers, references to 'atīk registers are also indicated. The appointment records are brief, but further detail can be found in the notes. If more explanation is needed, the notes indicate that other registers, particularly the tafșil registers, should be consulted for a detailed description of the appointment process.

\section{The Neighborhood and the awqā $f$ of Maghariba}

The presence of North Africans from Morocco, Tunisia and Algeria in Jerusalem dates back to the earliest periods of Islam. Known as the Maghribis,

15 Madrasa al-Afdaliyya (VGMA, 515: 78/88); Zāwiyat al-Maghariba (vgmA, 515: 79/89); Zäwiyat al-Fahriyya (VGMA, 515: 92/139); Waqf of Abu Madyan al-Ghawth and Sayyid 'Umar al-Mujarrad (VGMA, 515: 97/157); Tomb of the Buraq (VGMA, 515: 98/159).

16 Sometimes the name of the employee is recorded with his social status. For example, in the record of the Zawiya al-Fahriyya, the professor (mudarris) Sheikh Abdurrahman is recorded as a member of the ulema.

17 VGMA, 515: 79/89.

18 "Awqā $f$ of Sayyid 'Umar al-Mujarrad and Abu Madyan al-Ghawth and al-Hajj Kasım al-Maghribi ibn Abdullah and the Awqā $f$ of Hajj Necme bint Hajj Muhammed alMaghribi and Sayyid Muhammed ibn Hajj Abdullah al-Maghribi and Ismail ibn Hajj Muhammed al-Maghribi and Sayyide Cennet bint Hajj Muhammed al-Maghribi and Sayyide Hatice bint Muhammed al-Maghribi and Sayyid Muhammed ibn Ismail" (160: 50/378-79); "Hangah-1 Fahriyye" (160: 56/420-25); "Cāmi' al-Maghariba” (16o: 96/735-37). 
they travelled to Mecca for the Hajj pilgrimage and also visited Medina, where the tomb of Muhammad is located. At that time, they also visited Jerusalem, considered the third holiest city of Islam. ${ }^{19}$ Those who visited the Holy City typically stayed near the Masjid al-Aqsā. ${ }^{20}$ The Maghribis were also aware of the presence of Maghribi scholars in the city, which might explain why they travelled there.

Of these Maghribi scholars, Shu'aib Ibn al-Husain al-Andalusi, known as Abu Madyan al-Ghawth, was a celebrated traditionalist and mystic (d. AH 594/ $\mathrm{AD}$ 1197). He was the leading member of the Andalusian-Maghribi family of great learning and wealth. Tradition relays that his piety, learning, and munificence benefitted the holy city of Jerusalem. The head of the family, Shu'aib, along with other members, moved from Andalusia to Fez, which was then regarded as the chief city in the Maghreb. Later on, his brother 'Ali and his son Madyan immigrated to Egypt. Other members of the family moved later from Egypt to Jerusalem, where the Maghribi community was already well established. $^{21}$

A number of historians of Jerusalem date the establishment of the Maghariba neighborhood to the time of the Ayyubids. In 583/1193, after Saladin defeated the Crusaders, one of the most important foundations was established around the Haram al-Sharif area in Jerusalem by the governor of Damascus (582-592), 'Afdal Malik Nur al-Din 'Ali, son of Saladin.. ${ }^{22}$ Mujir al-Din relates that 'Afdal al-Din "endowed as waqf the entire neighborhood of the Maghribis in favor of the Maghribi community, without distinction of origin," and that the "donation took place at the time when the prince ruled over Damascus [AD 1186-1196], to which Jerusalem was joined."23 He simultaneously authorized the building of the Harat al-Sharaf neighborhood contiguous to the Maghariba neighborhood in what today is referred to as the Jewish Neighborhood. ${ }^{24}$ As a waqf endowment, the area was to serve as a destination for new arrivals from the Maghreb. From the thirteenth century until the final days of the Jordanian regime in 1967 , immigrants from the Islamic world visited and made this neighborhood their home. ${ }^{25}$

\footnotetext{
19 Güneş, "Kudüs'te Bir Mahalle," 10.

20 al-Asali, "Haratu'l-Maghariba fi al-Quds," 19.

21 Tibawi, Islamic Pious, 10.

22 Güneş, "Kudüs'te Bir Mahalle," 10-12.

23 See al-Hanbali, al-Uns al-Jalil, vol. 2, 397.

24 Ibid. See also Tibawi, Islamic Pious.

25 Abowd, "Moroccan Quarter," 6-16.
} 
The neighborhood is located in the extreme south of the Old City, and measures roughly 10,000 square meters. It became the site of a number of historically and culturally significant structures erected during the Ayyubid and Mamluk eras. These included Waqf al-Maghariba and Madrasa al-Afdaliyya, endowed by 'Afdal in this neighborhood during the latter part of the twelfth century for the use of Maliki jurists (fuqahā). ${ }^{26}$ Zāwiyat al-Maghariba, Mosque $\left(c \bar{a} m i^{i}\right)$ al-Maghariba, and zāwiy $a$ al-Fahriyya were other notable structures in the neighborhood at that time. ${ }^{27}$ Although during the seventeenth, eighteenth, and twentieth centuries, there were six, twelve, and three new awqāf established respectively, no new structures were built. All the founders of the awqāf were Maghribi residents of Jerusalem. Three of them were founded for the benefit of the public, one was a cash (nukūd) waqf, and the remaining twenty were modest and locally founded family awqāf (see table 4.1). The concentration of these religious, charitable and educational foundations in this particular area was undoubtedly due to its association in the Quran and Islamic tradition with Muhammad's miraculous nocturnal journey to Jerusalem. It is believed that the two stages of Muhammad's journey: al-Isrä $\bar{c}^{c}$ (the nocturnal journey) and al-Miraj (ascension) took place around the western wall of Haram al-Sharif and the Dome of the Rock. These miraculous events in Islamic tradition have endowed the area with a special importance for Muslims. For centuries, scholars and other travelers from all over the Muslim world have come to pray at the Haram and lodge in the sacred places mentioned in the verse: "Glory be to Him, who carried His Servant by night from the Holy Mosque [in Mecca] to the Farther Mosque [al-Masjid al-Aqsā], the precincts of which We have blessed ..."28

\section{a Waqfal-Maghariba}

The Maghribi waqf was founded by al-Malik al-Afdal Nurud-Din Ali, soon after the recapture of Jerusalem from the Crusaders. Al-Afdal was king (malik) in Damascus from AH 582 to 592. Malik al-Afdal dedicated the whole area outside the western walls of Haram al-Sharif, known as Hārat al-Maghāriba, as a waqf for the benefit of all Maghribis, male and female. In a series of

26 According to Donald Little, "The location of this school in the Maghariba Quarter was appropriate, since most of the Mālikīs traced their origins from North Africa." See his "Jerusalem under the Ayyubids and Mamluks, 1187-1516 AD," in Jerusalem in History, ed. Kamil Jamil al-Asali (Buckhurst Hill: Scorpion, 1989), 180.

27 See Michael Hamilton Burgoyne, Mamluk Jerusalem: An Architectural Study (London: British School of Archaeology for the World of Islam Festival Trust, 1987).

28 Kur'an-ı Kerim, Surah XVII, verse 1. 
documents, immigrants from the Maghreb and residents of Jerusalem were defined as "Western Tunisians, Algiers and Moroccans."29 The area was consequently turned into a neighborhood for Maghribi Muslims. ${ }^{30}$ As the name sharaf (honor) indicates, and as the occupations of the three prominent types of residents confirm, religious dignitaries and high government officials inhabited the area. ${ }^{31}$

This waqf had several forms of income. According to the Jerusalem sijillāt (Js), income was controlled by the sheikh of the neighborhood and disbursed among the community's population. To these incomes, Shu'aib Ibn Muhammad Ibn Shu'aib, generally known simply as Abu Madyan, grandson of Abu Madyan al-Ghawth, added his lands of the village of 'Ayn Karim near Jerusalem, the income of which was to benefit the Maghribis. ${ }^{32}$ However, in the Esās registers, there is no record specifically entitled "Waqf of Maghariba," but rather "Waqf of the Tombs of Abu Madyan al-Ghawth and "Umar al-Mujarrad."

\section{b Madrasa al-Afdaliyya}

Apart from being religious and charitable, al-Afdal's waqf was also educational in that he established a madrasa called al-Afdaliyya after him. According to the waqfiyya of the Afdaliyya madrasa, it was stipulated that the madrasa was created to train jurists in line with the Maliki school of jurisprudence, the dominant school in the Maghreb and the most prominent among the Maghrebi diaspora in Jerusalem. ${ }^{33}$ This madrasa was also called the "Dome" or "Dome of Afdaliyya," or sometimes "Madrasa al-Malikiyya" and was founded in the year $590 / 1193 \cdot{ }^{34}$

29 See for example воA, ŞD.2296.40.49, 22 Haziran 1319 [5 July 1903]/SD.2296.40.44, 21 Ağustos 1319 [3 September 1903]/SD.2296.40.36, 23 Ağustos 1319 [5 December 1319].

Mujir al-Din, al-Uns al-Jalil, vol. 2, 397. As Mujir al-Din states, the waqfiyya document seems to have been lost, but the waqf was recorded and legalized after the death of al-Afdal. This was done twice, once before Mujir al-Din wrote his history and once afterwards: in AH 666 and 1004 (AD 1267 and 1595), shortly after the beginning of the Mamluk period and some eighty years after the beginning of the Ottoman period, respectively. The following translation is a certified copy of the valid document (and a prefatory note confirming Mujir al-Din's statement), preserved at the shari'a Court in Jerusalem (Js 77: 588).

31 Tibawi, Islamic Pious, 10-13.

32 Ibid.

33 Mujir al-Din, al-Uns al-Jalil, vol. 2, 397.

34 VGMA, 1107:2/78. 
In the eighteenth-century registers, the appointment records of the madrasa appear along with the waqf of Abu Madyan al-Ghawth. ${ }^{35}$ Some of the other staff members such as the doorkeeper and the sweep were appointed and recorded separately. ${ }^{36}$ On the other hand, in the appointment registers, six employees were registered under the heading of "Madrasa al-Afdaliyya" between AD 1670 and 1825 (AH 1081-1241). The first employee was the mudarris, followed by his assistant (muid). ${ }^{37}$ While the fee of the mudarris was recorded as a certain unspecified amount (mu'ayyen), the assistant's fee was recorded as one kirsh daily. In the third and fourth registers, the collection clerks $\left(c \bar{a} b i{ }^{i}\right)$ were registered as receiving a half share. The fifth employee was a doorkeeper and sweep who was paid one kirsh daily. The last employee was the supervisor and inspector. However, there were no references to the waqf of the madrasa in the cedìd record.

\section{c Zāwiyat al-Maghariba}

By the middle of the fourteenth century, the considerable Maghribi community in Jerusalem, residing just outside the western wall of Haram al-Sharif between the two gates of Bab al-Silsala and Bab al-Maghariba, could benefit from two Maghribi waqf charitable foundations or zāwiya. The first zāwiya was established by an immigrant, 'Umar Ibn 'Abdullah Ibn 'Abdun-Nabi

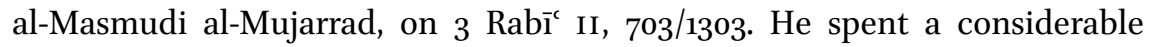
amount of his money on the endowment of a zawiy ${ }^{38}$ for the benefit of Maghribis living near Haram al-Sharif in a neighborhood named after them. ${ }^{39}$ This was the first waqf instituted by a Maghribi for the benefit of al-Maghariba in Jerusalem. There is a prayer lodge in the upper part of the zāwiya which had two floors. In the lodge, the poor of the Maghribis were received and their needs were met. ${ }^{40}$

The second $z \bar{a} w i y a$ was endowed in the same Maghariba neighborhood close to Bab as-Silsila, one of the gates of Haram al-Sharif, by Shu'aib Ibn Muhammad Ibn Shu'aib. ${ }^{41} \mathrm{He}$ was renowned for his scholarship and generosity

\footnotetext{
35 VGMA, 1107: 2/78; 1160: 116/42.

36 VGMA, 1109: 6/37; 1128: 68/28.

37 VGMA, 515: 78/88.

38 Literally a "retreat" for meditation and prayer, but also a hostel for dervishes and an educational establishment.

39 Mujir al-Din, al-Uns al-Jalil, vol. 2, 397, 580.

40 Tibawi, Islamic Pious, 10.

41 According to Tibawi, the attachment to Shu'aib as a first name and Madyan as a last name was probably inspired by the Qur'an. In the holy book, Shu'aib figures as one of God's prophets sent to Madyan (for example, Surah 7:85: "And unto Madyan did we send their
} 
among Maghribis who had settled in Jerusalem. As mentioned, he assigned the lands of the village of 'Ayn Karim near Jerusalem, his own property, as a waqf whose income was intended for the zāwiya and the Maghribis. ${ }^{42}$

During the eighteenth century, only the sheikh's appointment records were recorded. ${ }^{43}$ The records of the 515 appointment registers show that the duties of the sheikh and supervisor were shared by two members of the Maghribi family; Sheikh Osman Ibn Sheikh Muhammad al-Maghribi and Sheikh Abu Bakr Ibn of Sheikh Ahmed al-Maghribi. Each employee had a half share of the position and were paid 1.5 kirsh daily. In the register, at the end of the record, a short statement indicates that the confiscation of the administration of these two awqa $f$ was ordered in $1208 / 1794$. After that time, although the appointment of the sheikh to the zāwiya continued, ${ }^{44}$ the administration and control of the waqf were placed under the heading of "Waqf of the Tombs of Sayyid 'Umar al-Mujarrad and Abu Madyan al-Ghawth in Jerusalem."

Summaries of twenty-one appointment deeds (berāt) appear in the records under the heading of this waqf. Two records refer to the renewal of the appointment deeds after the coronation of a new sultan. ${ }^{45}$ There is a note dated 15 Șafar 1195 [February 10, 1781] under the heading of the waqf, stating that the people who had been appointed supervisor, instructor, and keeper of the tomb of the waqf were also appointed as the sheikh of the town criers. In a record dated 13 Safar 1198 [December 10, 1783], it is claimed that this was a long-standing tradition. ${ }^{46}$ The initial meaning of the verb dalla is "to

brethren Shu'aib." He is supposed to be Jethro of the Bible, the father-in-law of Moses. See Exod. 3:1, where the name is written Midian.)

Tibawi, Islamic Pious, 13. This copy of the Qur'an is preserved in the Islamic Museum in Haram al-Sharif.

43 VGMA, 1160: 116/18; 1109: 6/105; 1112: 1/36; 1112: 1/148; 1111: 54/55; 557: 43/3.

44 VGMA, 1111: 54/55; $557: 43 / 3$.

45 The first renewal was written on 11 Receb 1203 [07 April 1789]. (Cutūs berātı sitāde). The second renewal was dated 4 Cemāziyelahir 1223 [28 July 1808]. (Culūs-ı emr-i sherīf sitāde.) VGMA, 515: 97/157.

46 Because of the vacancy in the position, Sayyid Ahmed Effendi was appointed as supervisor, inspector, keeper of the tomb and the sheikh of the town criers in exchange for 7 kirsh ( $\dot{g} u r u ̄ s ̧)$ daily. In the first record, it was stated that the appointment deed (berāt) was received on 15 Safar 1195 [10 February 1781] along with his own petition and the appointment decree (ru'uss). In the second record about the same appointment, it is stated that the order (emr-i sheriff) was received on 15 Muharram 1198 [10 December 1783] with his own petition and the imperial edict (fermān). In the last record, it is stated that a detailed remark was written on 13 Safar 1198 [ 7 January 1784]. Furthermore, in a hurūfāt record dated Shawwāl 111 [March/April 1700], Sayyid Yakub al-Mansur al-Maghribi was appointed supervisor, inspector and keeper of the tomb as well as the sheikh of the 
indicate, to demonstrate and to show publicly." As a noun, dallāl becomes "a broker," "a middleman," in short, a dealer, but the guild kept exercising its original public-crying function as well. The members of this guild pledged to consult their head on every transaction and to obey his orders: "As long as he did nothing to antagonize the guild members and committed no offense (junha), he could proceed with his responsibilities. If, on the other hand, he could not properly conduct the guild's affairs, either because of health problems or due to his absence from town, the judge (qadi) replaced him immediately." In the seventeenth and eighteenth centuries, the head of the Maghariba neighborhood was granted the right to this position by official decrees from Istanbul. ${ }^{47}$ For Amnon Cohen, this was one of the most active guilds during the seventeenth century in Jerusalem.

This position was sought after by many, and created fierce competition that often ended in opponents sharing the leadership. People in these positions were also granted a daily stipend of eight $k \iota t t^{t} a$. The combination of a steady salary and a certain percentage of every guild was exceptional and made this position more lucrative and desirable than others. ${ }^{48}$

Regarding the first appointment, it is also noted that this was a precaution designed to prevent the intervention of the head of the palanquin artisans in matters concerning the town criers guild. ${ }^{49}$ However, the precaution was also related to the tax revenues ( $a$ ş̧är u rusūmāt $)$ of the village of 'Ayn Karim. According to this record, the tax revenues of the village would only be delivered to the poor of the zāwiya al-Maghariba. ${ }^{50}$ The last record, dated 26 Rabī II

town criers to the Waqf of Abu Madyan al-Ghawth. Then, in Shawwāl 1138 [June 1726], Sayyid Abdussalam al-Maghribi was appointed as the head of the town criers in the sūq of Jerusalem (VGMA 1091: 77/11).

47 VGMA, 515: 97/157; BOA, C.EV.566.28553 and C.EV.552.27881.

48 Amnon Cohen, The Guilds of Ottoman Jerusalem (Leiden: Brill, 2001), 178-79.

49 In a variety of documents recorded during different years of that century, there are recurrent attempts to wrest these lucrative positions from the head of the North Africans and invest the honor, and more importantly, the accompanying income, in other candidates. In this case, for example, the head of the palanquins' guild (tahteravanci bashi) claimed that he had been granted this position by a sultanic decree from Istanbul, although the head of the North African descendants of the Prophet in town insisted that, upon the death of his predecessor, he had been put in charge of both functions. As it turned out, the outside contender had been appointed under false pretenses, in violation of the incontestable link established for generations among all these functions. Thereupon the qadi confirmed the status quo, to the disadvantage of "the foreigner," who had tried to usurp it. VGMA, 515: 97/157; for other examples see Cohen, Guilds, 178-83. 
1277 [December 11, 186o], references Jerusalem Cedìd register number 16o. This illustrates the consistency between the old and new series. After this date, three more appointments were recorded. In the first record, dated Dhū al-Qa'dah 1301 [September 1884], it is stated that after Mehmed Arif Effendi's passing away, al-Hajj 'Umar al-Maghribi, the oldest, most mature and most suitable candidate in the Maghariba neighborhood, was appointed to the waqf as its supervisor (mutawalli), inspector (nāzır), and keeper of the tomb (türbedār) by a petition and an imperial edict. ${ }^{51} \mathrm{After}$ this date, there are no references to the sheikh of the town criers. We do not know whether the post continued to be held by the head of the neighborhood.

The second record, dated 15 Muharram 1321 [April 13, 1903], states that there was a trial concerning the administration of the awqāf. During the trial, waqf lands and properties could not be rented to any tax farmers. The record states that the keeper of the Tomb of the Prophet David or any other trustworthy man would be appointed as temporary deputy supervisor by the waqf governorship. ${ }^{52}$ The correspondence concerning these issues was reported to all the related departments as ordered in the imperial edict. In the third and last record, it is stated that after the death of Maghribi Sheikh Mehmed Arif Effendi, according to the conditions stipulated in the waqfiyya and procedures applied as usual, Maghribi al-Hajj Bashir Effendi, son of Abdussalam al-Hasani, was appointed as the supervisor, inspector, and keeper of tomb of the waqf on 28 Dhū al-Hijjah 1329 [December 20, 1911].53 The records of the "Waqf of the Tombs of Sayyid 'Umar al-Mujarrad and Abu Madyan al-Ghawth in Jerusalem" end with this record.

The 'atīk and cedīd appointment registers that started with zāwiyat alMaghariba on 18 Dhū al-Qa'dah 1134 [August 30, 1722] are grouped under the heading of the waqf of the Tombs of Sayyid 'Umar al-Mujarrad and Abu Madyan al-Ghawth on 15 Ṣafar 1195 [February 10, 1781]. All the public awqā $f$ of the neighborhood are grouped thereafter under the heading "Awqâf of Sayyid 'Umar al-Mujarrad and Abu Madyan al-Ghawth and al-Hajj Kasım al-Maghribi ibn Abdullah and the awqāf of Hajj Necme bint Hajj Muhammad al-Maghribi and Sayyid Muhammad ibn Hajj Abdullah al-Maghribi and Ismail ibn Hajj Muhammad al-Maghribi and Sayyide Cennet bint Hajj Muhammad al-Maghribi and Sayyide Hatice bint Muhammad al-Maghribi and Sayyid Muhammad

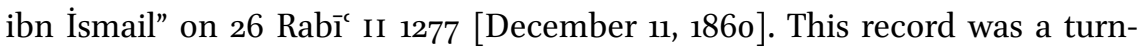
ing point for the awqā of the neighborhood since both the public and family $a w q \bar{a} f$ were combined and administered together. It was not a confiscation,

\footnotetext{
$51 \quad$ VGMA, $160: 378$.

52 VGMA, Tafsïl 405 .

53 VGMA, Tafsïl 202.
} 
awqā $f$ were still run by families, but their administration was united by the central authority. In the registers, corruption and mismanagement of the awqā $f$ were listed as the main reasons for the changes in the waqf administrative staff. ${ }^{44}$ The last waqf added to this administratively united structure was the Waqf of the Descendants of the Prophet (sādāt) of Maghariba, which will be discussed further on.

\section{d Cāmi al-Maghariba}

Al-Maghariba Mosque, near the Bab al-Maghariba, ${ }^{55}$ was constructed northsouth to the Haram al-Sharif area and it was considered an integral part of the Haram. ${ }^{56}$ There are no records of the mosque in Jerusalem's 'atîk register, but in the cedid register of the waqf, there is a note stating that the 'atīk registers of the waqf were recorded in the Mecca and Medina 'atīk register numbered 92. ${ }^{57}$ In the cedid, three employees were appointed, but the Treasury later decided that one employee should be appointed at 50 kirsh monthly for all these duties. The name of the waqf was also recorded as "Evkāff-ı mażbütadan Kudüs-i Şerīfde kāin Meḡāribe Cämi'-i Şerîfi Vakfi," meaning that this waqf had already been administered by the representatives of the central authority.

\section{e Madrasa and zāwiyat al-Fahriyya}

Madrasa al-Fahriyya is also known as the zäwiyat al-Fahriyya in the Jerusalem court registers, and was founded by Qadi Fahreddin Muhammad ibn Fadlullah in 732/1331. The madrasa was situated to the west of al-Maghariba Mosque and remained within the walls around the mosque. The library of the madrasa played an important role among Jerusalem's public libraries. Founded by Qadi Fahreddin in 732/1339, this library is said to have housed approximately 10,000 volumes. Its collection of manuscripts on astronomy and religious sciences has

54 For the details of the records, see zāwiya of Maghariba (VGMA, 515: 79/89); Waqf of Abu Madyan al-Ghawth and Sayyid 'Umar al-Mujarrad (vgma, 515: 97/157); Awqāf of Sayyid 'Umar al-Mujarrad and Abu Madyan al-Ghawth and al-Hajj Kasım al-Maghribi ibn Abdullah and the Awqā $f$ of Hajj Necme bint Hajj Muhammed al-Maghribi and Sayyid Muhammed ibn Hajj Abdullah al-Maghribi and İsmail ibn Hajj Muhammed al-Maghribi and Sayyide Cennet bint Hajj Muhammed al-Maghribi and Sayyide Hatice bint Muhammed al-Maghribi and Sayyid Muhammed ibn İsmail (160: 50/378-79).

55 Burgoyne, MamlukJerusalem.

$5^{6}$ Although Mujir al-Din says the mosque was built during the second caliph's visit to Jerusalem, this is a very remote possibility. The general consensus is that this mosque was built during the Umayyad period, based on the inscription on the eastern entrance to the mosque, which states Sultan Abdülaziz repaired it in the year 1288/1871. Güneş, "Kudüs'te Bir Mahalle," 10-12.

'Atīk Mecca and Medina, 92. 
been lost. ${ }^{58}$ The Fahriyya Bazaar was among the most important sources of joint income of the madrasa and the zäwiya. The revenue from the shops in the bazaar was spent on each waqf's expenses. In 978/1570, repair and maintenance of the lodge was carried out by the Ottomans and cost 25 gold coins. ${ }^{59}$

In Jerusalem's 'atîk appointment register, four employees were appointed as mudarris, ${ }^{60}$ two sheikhs of the lodge with half salaries and an inspector. The last appointment was dated 16 Rabī 'iI 1294 [April 30, 1877]; subsequently the record was transferred to the 160 Jerusalem Cedid appointment register. These Cedid records show that two new employees whose shares were onethird of a neighborhood were appointed after of the death of the former staff. The last record is dated 20 Muharram 1318 [May 20, 1900].

What is striking about this record is that the duties and the salary of the sheikh in the lodge were divided among seven employees. Two of the employees were allocated half of one neighborhood, and the remaining five received one third of a neighborhood as daily income. Furthermore, all of the employees were relatives of the former employees. This was maintained by the imperial edicts and orders sent by the central authority. ${ }^{61}$ During the eighteenth and the first half of the nineteenth centuries, shared waqf duties were very common because of the privileges linked to the 'akseri appointment deeds (berāt) and the economic conditions of the period. ${ }^{62}$ These duties conferred social status, economic power, and exemption from taxes, which made them attractive to the common people $\left(r e^{\top} \bar{a} y \bar{a}\right) .{ }^{63}$

Another public waqf structure recorded in the registers is the Tomb of al-Buraq (Makām al-Buraq al-Arbainn). In the 'atīk register of the neighborhood, four records describe the appointment of the sheikh for the tomb. ${ }^{64}$ However, we do not know whether this tomb was a different structure in that spot or whether it was the masjid discussed earlier. The "Waqf of al-Hajj

58 'Arif al-Arif, al-Mufassal fi tarikh al-Quds [A detailed history of Jerusalem] (Jerusalem, 1961), 451.

59 Güneş, "Kudüs'te Bir Mahalle," 12.

6o Holding the title of mudarris meant that one had completed the course of study at one of the recognized teacher-training madrasas of Istanbul, Edirne or Bursa, and that one was qualified to teach. See Madeline C. Zilfi, The Politics of Piety: The Ottoman Ulema in the Postclassical Age, 1600-180o (Minneapolis: Bibliotheca Islamica, 1988).

61 See for example VGMA, 814: 11.

62 Mohammad Ali al-Alami, "The Waqfs of the Traditional Families of Jerusalem during the Ottoman Period," in Ottoman Jerusalem: The Living City, 1517-1917, ed. Sylvia Auld and Robert Hillenbrand (London: Altajir World of Islam Trust, 2000).

63 Hülya Canbakal, Society and Politics in an Ottoman Town: Ayntäb in the 17th Century (Leiden: Brill, 2007), 83-84.

64 VGMA, $515: 98 / 159$. 
Kasım al-Maghribi ibn Abdullah" is recorded under the heading of "Waqf of the Tombs of Sayyid "Umar al-Mujarrad and Abu Madyan al-Ghawth" in 1860. Lastly, "the waqf of the descendants of the Prophet in the neighborhood" (Waqf of Sādāt-ı Maghariba) appears in the Cedìd appointment register of the Maghariba. Ahmed al-Maghribi was appointed supervisor of the waqf on 15 Safar 1194 [February 21, 1790]. This is the only record in the register. A reference to the 'atīk appointment register indicates that the administration of the waqf was handled jointly by 'Umar al-Mujarrad and Abu Madyan al-Ghawth. Like other family awqāf, the status of this waqf did not change. In 1860, it was grouped with the public awqāf..$^{65}$

\section{Appointment Registers as Archival Sources for Waqf Studies: Ottomanization and Integration of the Local Elites}

All of the public awqā $f$ in the neighborhood are recorded in the registers. Updated details including changes in the administration of the $a w q \bar{a} f$, and the reasons for these changes, can also be traced. Some of the centralization measures implemented by the central authority from the very beginning of the establishment of the Ministry of Awqā $f$ in 1826 can also be observed in the records. In the Maghariba neighborhood, thanks to the measures taken in 1860, all the awqā $f$ in the neighborhood were combined and administered together. As a result, the duties of the public and family awqā $f$ in the neighborhood were recorded. The records also detail the mismanagement of the awqa $f$ in the neighborhood and show that some of the revenue of the newlyestablished family awqā $f$ was added to public awqāf. However, the residents of the neighborhood continued to administer these institutions under greater supervision of the central authorities during the nineteenth century.

This analysis of the waqf records of the Maghariba neighborhood shows that these institutions were managed by the residents for centuries, creating a local network within the neighborhood. The records also show that during the eighteenth and nineteenth centuries, corruption and the mismanagement of waqf properties were rampant. In an attempt to control the situation, the waqf structure was united administratively and control was centralized. Both public and family awqāf in the neighborhood were administratively combined in 1860 , yet certain records show that some employees continued to be appointed separately. These registers were part of a bureaucratic mechanism that allowed the central authority to exercise strict control over the administration 
of $a w q \bar{a} f$ through appointments to waqf posts. The organization of the $a w q \bar{a} f$ in Jerusalem through the local Ottoman bureaucracy facilitated this strict control. Ottoman bureaucracy thus included waqf administration, and incorporated a network of scholars (ulema; Ar. 'ulamả) into the state's bureaucratic, economic and administrative structure. ${ }^{66}$

The registers also reveal the changes in the number of waqf staff and show how these numbers differentiated from the original waqfiyya over time as a result of these new appointments. Ottoman bureaucracy was able to establish itself locally through these new appointments. ${ }^{67}$ This meant that local people became involved in the administrative and distributive networks of the imperial center. A newly formed elite class was integrated into the system as Ottoman bureaucracy was introduced to local affairs.

The decentralization expressed in the concept of Ottomanization ${ }^{68}$ also meant a "restructuring" of Ottoman administrative mechanisms and the

66 Gabriel Baer, “Jerusalem's Families of Notables and Waqf in the Early 19th Century," in Palestine in the Late Ottoman Period, ed. David Kushner (Leiden: Brill, 1986), 109-23; al'Alami, "Waqfs"; Şerife Eroğlu Memiş, "Waqfs as a Tool for the Rise of Local Notables in Jerusalem During the 18th Century" (paper presented at the 46th annual meeting of the Middle East Studies Association, New Orleans, 2016). For a detailed analysis on the case of Damascus, see Richard van Leeuwen, Waqfs and Urban Structures: The Case of Ottoman Damascus, (Leiden: Brill, 1999), 133-63.

67 Canbakal, Society and Politics, 82; Ali Yaycıoğlu, "Sened-i İttifak (1808): Osmanlı İmparatorluğu'nda Bir Ortaklık ve Entegrasyon Denemesi” [Charter of alliance (1808): a partnership and integration experiment in the Ottoman Empire], in Nizam-ı Kadimden Nizam-ı Cedide: III. Selim ve Dönemi [Selim III and his era from ancien régime to new order], ed. Seyfi Kenan (Istanbul: ISAM, 2010).

68 Fundamental changes occurred in the relationship between the Ottoman state and the elites in the provinces during the eighteenth century. Moreover, these changes differed from province to province. Some historians have argued that a large part of the local elites were Ottomanized in the eighteenth century. According to them, this Ottomanization functioned as an antidote to the disintegration of the central control that had developed considerably in the late 170os. While Jane Hathaway, in The Politics of Households in Ottoman Egypt: The Rise of the Qazdağlis (Cambridge: Cambridge University Press, 1998), does not use the term Ottomanization in her study, in which she argues that a distinctly Ottoman elite political culture was transferred to Egypt. She does indicate that the secondary management environment spread to the Ottoman provinces. By contrast, Bruce Alan Masters, in The Origins of Western Economic Dominance in the Middle East: Mercantilism and the Islamic Economy in Aleppo, 1600-1750 (New York: New York University Press, 1988), appraises these groups as part of the emergent Ottoman upper class, and Dina Rizk Khoury, in State and Provincial Society in the Ottoman Empire: Mosul, 1540-1834 (Cambridge: Cambridge University Press, 1997), defines the process as Ottomanization. 
relations between center and periphery. ${ }^{69}$ By integrating provincials into the imperial institutional framework, Ottoman power in the provinces was increased, on the one hand, while the empire's traditional administrative structure was transformed, on the other. The Ottoman center had no other choice than to provide the provinces with resources and to integrate the provincial forces into its own structure to ensure local security and surveillance. However, this integration did not result from a vertical appointment process from the central to the regional, but rather from a horizontal process of ongoing negotiation and consensus. ${ }^{70}$

In terms of the relations between the Ottoman authorities and its provinces, this view is contrary to the claim that central control was gradually relaxed and local powers became more independent during the eighteenth century. Rather, central authority was strengthened, not only through the enactment of strict bureaucratic centralization measures, but also by monitoring events through the appointment of officers with strong local ties and decent stipends. This control was also enforced by careful appointment policies and authorizations to families to build a power base that ensured stability in the local power structures. The awqāf functioned as an important mechanism for central control because they served to form and integrate relationship networks and institutions, and hence to monitor them. At the same time, by including the economic network to state officers in its administration, the state was able to supervise waqf institutions and could implement its own policies. ${ }^{71}$

69 See Karl K. Barbir, Ottoman Rule in Damascus, 1708-1758 (Princeton: Princeton University Press, 1988); Rifa'at Abou-el-Haj, Formation of the Modern State: The Ottoman Empire, Sixteenth to Eighteenth Century (Albany: State University of New York Press, 1991); Ariel Salzmann, 'An Ancien Régime Revisited: 'Privatization' and Political Economy in the Eighteenth-Century Ottoman Empire," Politics and Society 21, no. 4 (1993); Dina Rizk Khoury, State and Provincial Society, Karen Barkey, Bandits and Bureaucrats: The Ottoman Route to State Centralization (Ithaca: Cornell University Press, 1994), and Jane Hathaway, "Rewriting Eighteenth-Century Ottoman History," Mediterranean Historical Review 19, no. 1(2004):37. For critical comments on the issue, see Leslie Peirce, "Changing Perceptions of the Ottoman Empire: The Early Centuries," Mediterranean Historical Review 19, no. 1 (2004).

$70 \quad$ Yaycioğlu, “Sened-i İttifak (1808)," 667-709.

71 Van Leeuwen, Waqfs and Urban Structures, 133-63. 
In the case of the awqā $f$ of the Maghariba neighborhood, the Ottoman state maintained the same policies. Waqf employees were appointed from among the leading scholars of the neighborhood. As seen in the records, nearly all the employees were members of the ulema of the neighborhood. Apart from stipends and tax exemption, the waqf staff enjoyed accrued prestige in society. The Ottoman state also retained the loyalty of these notables through grants provided to them and to the poor of the community during the period under review. Two important devices that were implemented were food allocations from the al-Imara al-Hasekiyya and the surra incomes sent from Istanbul. This included allocations for bread, provided daily by the al-Imara al-Hasekiyya, for the employees of zāwiya Abu Madyan al-Ghawth and $z \bar{a} w i y a$ al-Buraq. ${ }^{72}$ In addition, allocations were distributed through the surra grants. Surra is a general term that refers to all of the money, gifts, and goods sent to the people in Haramayn during hajj season by the Ottoman Empire. ${ }^{73}$ As in previous centuries, these grants were earmarked for Jerusalem, and they continued being distributed during the nineteenth century. ${ }^{74}$ The last surra register found in the records is dated $1318 / 1900$. The prayer recitants, muezzins, and other employees of the al-Maghariba Mosque were recorded among the prayer reciters of Masjid al-Aqsā and the Dome of the Rock. Grants also

72 See for example воА, EV.d.13645; воА, EV.d.18277; воА, EV.d.18617; воА, EV.d.19214.

73 The tradition of sending surra to Haramayn started during the time of al-Muktedir Billah, one of the Abbasi Caliphs (311/923-924). Later states continued this tradition. The Ottoman Empire began to send surra to Haramayn during the reign of Bayezid I (Ylldırım Bayezid). The regular transfer of Surre-i Hümāyūn (dynasty surra) started during the reign of Yavuz Sultan Selim (Selim I). As one of the principal sources of Ottoman political history in the chronicle of Aşıkpaşa-zāde, while talking about Murat II, he also stated that the sultan sent gifts and money to Mecca and Medina as well as to Jerusalem and Hebron. It is not clear if this was sent within the context of surra or not. Beginning with the conquest of the city by Selim II in 1516, there was a great deal of help and assistance provided to the city. However, the oldest surra register associated with Jerusalem is dated 1593. The registers state the amount and the consignee of the gifts and assistance sent to these holy cities regularly on an annual basis. For detailed information, see Sit Tufan Buzpınar; "Surre" [Surra], DIA - Türkiye Diyanet Vakfi İslam Ansiklopedisi [Turkish Religious Foundation Encyclopedia of Islam], vol. 37 (Istanbul: TDV, 2009), 567; Münir Atalar; Osmanlı Devletinde Surre-i Hümayun ve Surre Alayları [Surra-i Humayun and surra regiments in the Ottoman state] (Ankara: Diyanet İşleri Başkanlığı, 1991), 12.

74 For more detailed information about the surra allocations in Jerusalem during the eighteenth and the first decades of the nineteenth centuries, see Eroğlu Memiş, Osmanlı Taşra Toplumu, 266-74. 
supported the poor of the Maghariba neighborhood together with the Risha neighborhood. The latter group was made up of the scholars and the poor of zāwiyat al-Maghariba. The amount of the grants remained constant throughout this time.

\section{The Power of Archives}

There is a historical link between the conservation of documents and the control exerted by a central authority. In the case of Jerusalem, the central authority - the Ottoman state - maintained control through strict appointment policies on questions of waqf administration..$^{75}$ Comprehensive files on the administration of Jerusalem were preserved in Istanbul. This situation was not limited to the imperial awqāf, whose supervisors were called to Istanbul from time to time for the inspection of these files. These appointment registers can be considered part of this bureaucratic process because they also include regularly updated summaries of appointment deeds (berāts) of waqf staff. To monitor the appointment of waqf staff and remain informed about conflicts concerning the execution of duties, Istanbul demanded oversight of these registers. The preservation and continuous indexation and updating of these registers thus enabled the central authority to exert its control.

In this sense, the 'atikk and cedid appointment registers provide valuable insight into the administration of the awqāf and their effects on social and economic life from the start of the seventeenth century until the end of the Ottoman Empire. Like the awqā $f$ of the Maghariba neighborhood, these registers deserve much more historical attention, given that they reveal the changing nature of the awqā $f$ and divergences from the conditions stipulated in the waqfiyyāt over time.

75 Leeuwen, Waqfs and Urban Structures, 163; see also Mosa Sroor, Fondations pieuses en movement: De la transformation du statut de propriété des biens waqfs à Jérusalem (18581917) (Damascus: Institut français du Proche-Orient (Ifpo); Aix-en-Provence: Institut de recherches et d'études sur le monde arabe et musulman (IREMAM), 2010), 461. 
TABLE 4.1 List of the waqfiyyāt of Maghariba neighborhood

\begin{tabular}{llll}
\hline No. & Date & Founder of the waqf & Properties of the waqf \\
\hline 1 & 4 Rajab & 'Afdal Malik Nur al-Din & Maghariba neighborhood \\
& $\begin{array}{l}\text { 666/April 9, 1268 } \\
\text { (26 Sha'bān } 1004 / 1595)\end{array}$ & 'Ali, son of Saladin & \\
& &
\end{tabular}

23 Rabīi I $^{\circ}$

703/October 15, 1303

329 Ramadān

$720 /$ November 2, 1320

$4 \quad 753 / 1352$

$5 \quad 5$ Dhū al-Hijjah 1021/January 27, 1613

$6 \quad 10 \operatorname{Rabīi~}^{\mathrm{c}} 1033$ /

January 1,1624

$7 \quad 1048 / 1631$

$8 \quad 15$ Ramadān 1058/

February 3, 1648

95 Rabī' II 1063/March 5 , 1653

$10 \quad 12$ Jumāda I 1088/

July 13,1677

11 Evāhir-I Shawwāl 1134/

August 12, 1722

1213 Muharram

1137/October 2, 1724

$13 \quad 1137 / 1727$
'Umar al-Mujarrad ibn

Abdullah al-Maghribi

Abu Madyan Shu'aib

al-Maghribi

'Ali ibn 'Uthman ibn Yảqub

ibn 'Abdul-Haqq al-Marini,

King of al-Maghrib

Muhammad ibn Ismail

Beshe al-Lumdani

al-Maghribi

Isa bin Ahmed ibn

ez-Zeim al-Maghribi

Al-Haje Necme bint Hajj

Mehmed al-Maghribi

al-Haje Safiye bint

Abdullah al-Jazairiyya

al-Maghribiyya

Meryem bint Abdülkadir al-Maghribi

Al-Hajj Kasım ibn al-Attavi

al-Maghribi

Al-Hajj Muhammad ibn

Ebubekir al- Maghribi

Al-Hajj Kasım ibn Abdullah

al-Maghribi al-Marakashi

ibn Ali al-Shaybani

Abdussalam ibn Ibrahim

al-Jalili ibn Muhammad

ibn Ibrahim al-'Uthmani

al-Maghribi
Three houses in Maghariba neighborhood

1. Village of 'Ayn Karim

2. A house situated in Bab al-Silsila

A copy of the Qur'an which he himself wrote

A house with a garden in Maghariba neighborhood and neighbor to the Waqf of Abu Madyan

A house in Hatt-ı Merziban

A house in Maghariba neighborhood

350 Esedī kirsh

A house in Maghariba neighborhood

A house in Maghariba neighborhood

A house in Maghariba neighborhood

A ruined house in

Maghariba neighborhood

A house in Maghariba neighborhood with a share of $1 / 213 \mathrm{kur}$ 'at 


\section{Conditions Public/Family Sources}

Maghribis Public Jerusalem Court Sijillāt

(Js) 77: 588; Abdullatif Tibawī, Awqāf al-Islāmiyya bi-Jiwār al-Masjid al-Aqsā, Vezārat al-Awqāf wa al-Şuūn wa al-Muqaddasāt al-Islāmiyya, Jordan 1404-1981, 13-17

The poor of Maghariba

Public Archive of the General Directorate of neighborhood and visitors of Haram al-Sharif

The Maghribis who live in Maghariba neighborhood and visitors to Haram al-Sharif Al-Aqsā Mosque

Public Foundations of Turkey (VGMA) 583: $28 / 21$

Public VGMA 583: 27/20

Zāwiya Abu Madyan

Family al-Alami, Waqfiyyāt al-Maghariba, 167-69

Dome of the Rock and al-Aqsā Family

JS 107: 227 .

Mosques

For the feeding of the poor of

Family

VGMA 589: 119/332

Maghariba neighborhood

For the feeding of the poor of Maghariba neighborhood

Public (cash) JS 141:41; al-Alami, Waqfiyyāt al-Magharibah, 53-55

The poor of Maghariba

Public

JS 146: 207; al-Alami, Waqfiyyāt

neighborhood al-Maghariba, 1-11

Cihātü'l-bir (ber)

Public

Js 179: 288

Waqf of Abu Madyan

Family

JS 218: 567

The poor of Maghariba

Family

al-Alami, Waqfiyyāt al-Maghariba, neighborhood 42-45; VGMA 583: 28/22

The poor of Jerusalem

Family

JS 218: 486 
TABLE 4.1 List of the waqfiyyāt of Maghariba neighborhood (cont.)

\begin{tabular}{|c|c|c|c|}
\hline No & Date & Founder of the waqf & Properties of the waqf \\
\hline 14 & $\begin{array}{l}10 \text { Rajab } \\
1141 / \text { February } 9,1729\end{array}$ & $\begin{array}{l}\text { Abdussalam al-Maghribi } \\
\text { (sheikh al-Maghariba) }\end{array}$ & $\begin{array}{l}\text { A house in Maghariba } \\
\text { neighborhood }\end{array}$ \\
\hline 15 & $\begin{array}{l}1 \text { Shacbān } \\
1153 / \text { October 22, } 1740\end{array}$ & $\begin{array}{l}\text { Muhammad el-Maghribi, } \\
\text { known as al-Gazzal, and } \\
\text { al-Hajj Muhammad } \\
\text { at-Tawil }\end{array}$ & $\begin{array}{l}\text { A multistory house in the } \\
\text { Damascus Gate } \\
\text { neighborhood, close to } \\
\text { the Dome of Hamra }\end{array}$ \\
\hline 16 & $\begin{array}{l}\text { 10 Rabī' II } \\
1158 / \text { May 12, } 1745\end{array}$ & $\begin{array}{l}\text { Abdullah Agha ibn } \\
\text { al-Hajj Muhammad } \\
\text { al- Maghribi }\end{array}$ & $\begin{array}{l}\text { A house in the Sharaf } \\
\text { neighborhood with a } \\
\text { share of } 12 \text { kir'at }\end{array}$ \\
\hline 17 & $\begin{array}{l}13 \text { Rajab } \\
1171 / \text { March 23, 1758 }\end{array}$ & $\begin{array}{l}\text { Ismail ibn Hajj Muhammad } \\
\text { Lemedani el-Maghribi }\end{array}$ & $\begin{array}{l}\text { A house in the Hutta Gate } \\
\text { neighborhood }\end{array}$ \\
\hline 18 & $\begin{array}{l}1 \text { Rabī' I } \\
1181 / \text { July } 28,1767\end{array}$ & $\begin{array}{l}\text { Hatice ve Cennat bint } \\
\text { al-Hajj Muhammad } \\
\text { Agha al-Hodja at-Tawil } \\
\text { al-Maghribi }\end{array}$ & $\begin{array}{l}\text { A storey house in the } \\
\text { Damascus Gate } \\
\text { neighborhood }\end{array}$ \\
\hline 19 & $\begin{array}{l}\text { Rabī`c II } \\
1185 / \text { July 14, } 1771\end{array}$ & $\begin{array}{l}\text { Al-Hajj Ali ibn Ahmed } \\
\text { al-Maghribi }\end{array}$ & $\begin{array}{l}\text { A house in the Cotton Gate } \\
\text { neighborhood }\end{array}$ \\
\hline 20 & $\begin{array}{l}\text { 10 Jumāda I } \\
1187 / \text { July 10, } 1774\end{array}$ & $\begin{array}{l}\text { Al-Hajj Ali ibn Ahmed } \\
\text { al-Maghribi }\end{array}$ & $\begin{array}{l}\text { A house in the } \\
\text { Hutta Gate neighborhood }\end{array}$ \\
\hline 21 & $1196 / 1782$ & $\begin{array}{l}\text { as-Sayyid M ibn Hajj } \\
\text { Abdullah al-Maghribi }\end{array}$ & $\begin{array}{l}\text { A house in the Shark } \\
\text { neighborhood }\end{array}$ \\
\hline 22 & 5 Muharram 1205/1791 & $\begin{array}{l}\text { as-Sayyid Muhammad } \\
\text { ibn Ismail Beshe } \\
\text { (al-Lemdānī al-Maghribi) }\end{array}$ & $\begin{array}{l}\text { Vegetable garden (hakūra) } \\
\text { consisting nursery and trees } \\
\text { from Abu Madyan waqf }\end{array}$ \\
\hline 23 & $\begin{array}{l}5 \text { Dhū al-Qa'dah } \\
1349 / 1931\end{array}$ & $\begin{array}{l}\text { Idris ibn al-Hajj Musa } \\
\text { ibn al-Hajj Hasan } \\
\text { al-Kasri al-Maghribi }\end{array}$ & $\begin{array}{l}\text { A house in the Sa'diyya } \\
\text { neighborhood, close to } \\
\text { the vegetable garden of } \\
\text { Mawlawiyya }\end{array}$ \\
\hline 24 & $\begin{array}{l}25 \text { Dhū al-Hijjah } \\
1349 / 1931\end{array}$ & $\begin{array}{l}\text { Idris ibn al-Hajj Musa } \\
\text { ibn al-Hajj Hasan } \\
\text { al-Kasri al-Maghribi }\end{array}$ & $\begin{array}{l}\text { 1. A house in the Damascus } \\
\text { Gate neighborhood } \\
\text { 2. Two shops in the Silsila } \\
\text { Gate neighborhood with } \\
\text { the share of } 17.5 \text { kurat and } \\
1 / 2 \text { kurat }\end{array}$ \\
\hline 25 & $\begin{array}{l}7 \text { Jumāda I } \\
1356 / 9,1937\end{array}$ & $\begin{array}{l}\text { al-Hajj Mes'ud ibn } \\
\text { Bilal known as al-Susi } \\
\text { al-Maghribi }\end{array}$ & $\begin{array}{l}\text { Two rooms in Maghariba } \\
\text { neighborhood and } \\
6 \text { o cuneyh cash }\end{array}$ \\
\hline
\end{tabular}




\section{Conditions Public/Family Sources}

Zāwiya Abu Madyan Jamily JS 222: 66

To Haramayn (Mecca and

Family JS 230: 240-41

Medina) and the Dome of

the Rock

Zāwiya Abu Madyan

Family

JS $235: 318$

Zāwiya Abu Madyan

Family

VGMA 589: 195/331

For the Maghribis staying in

Family

JS 250: 17-18. al-'Alamī, Waqfyyāt

the Zāwiya Abu Madyan

al-Maghariba, 25-27; VGMA 589:

$192 / 328$

Waqf of Maghariba

Family

JS 253: 70-71

Rawāk Abu Ferve that belong

Family

JS 255: 47

to the Maghribis

Family

VGMA 589: 192/327

Family

VGMA 589: 194/330; JS 272, 134-35

Division of the incomes

Family

JS 404: 19-21

between the (Dārü'l-Eytāmü'l-

Issāmiyye es-Sınāiyye) and his

family

Muslim Orphanage House

(Dārül-Eytāmül-İslāmiyye)

Family

JS 454: 19-21

Waqf of Maghariba

Family

JS 474: $133-34$ 